\title{
Comparison between freeze and spray drying to obtain powder Rubrivivax gelatinosus biomass
}

\author{
Comparação entre a secagem por liofilização e atomização para produção de biomassa bacteriana
}

\author{
Edson Francisco do Espírito SANTO ${ }^{1 \star}$, Leandro Kanamaru Franco de LIMA ${ }^{1}$, \\ Ane Pamela Capucci TORRES ${ }^{1}$, Gabriela de OLIVEIRA² ${ }^{2}$, Elisa Helena Giglio PONSANO ${ }^{1}$
}

\begin{abstract}
The use of colorants in products of animal origin is justified by the improvement in the color of foods since this attribute is considered a quality criterion. These additives can be produced using industrial effluents as substrates and appropriate organisms, such as Rubrivivax gelatinosus. Oxycarotenoids represent a class of carotenes responsible for the pigmentation of animals and vegetables. R. gelatinosus grows in fish industry effluent with the resulting production of a bacterial biomass containing oxycarotenoids. The purpose of this study was to compare the use of two drying processes - spray and freeze drying - to obtain powder biomass in terms of the process parameters (yield, productivity, and product recovery) and the product characteristics (color, proximate composition, and oxycarotenoids). No difference was detected in the yield between these techniques, while productivity was higher using spray drying. Higher product recovery and moisture were achieved with freeze drying, while ash was higher with spray drying. The freeze dried biomass was redder, darker and less saturated than the spray dried biomass. No difference in oxycarotenoids was detected between the biomasses. Although it results in lower recovery rate, spray drying was faster and more productive, and it provided the same yield as freeze drying, which makes it the method of choice for obtaining $R$. gelatinosus biomass. Keywords: biomass; biological pigments; Rubrivivax gelatinosus.
\end{abstract}

\section{Resumo}

O uso de corantes em produtos de origem animal justifica-se pela melhora na cor dos alimentos, uma vez que este atributo é considerado um critério de qualidade. Estes aditivos podem ser produzidos utilizando efluentes industriais como substratos e organismos adequados, como Rubrivivax gelatinosus. Oxicarotenóides representam uma classe de carotenos, responsáveis pela coloração de animais e vegetais. $R$. gelatinosus cresce em efluente de indústria de pescado produzindo biomassa contendo oxicarotenóides. O objetivo deste experimento foi comparar duas metodologias para obter a biomassa seca - atomização e liofilização - em relação aos parâmetros do processo (rendimento, produtividade, recuperação) e sobre as características dos produtos (cor, composição centesimal, oxicarotenóides). As técnicas não diferiram quanto ao rendimento, enquanto que a produtividade foi maior para a atomização. A maior recuperação e a maior umidade foram obtidas pela liofilização, enquanto que a concentração de cinzas foi maior com a atomização. A biomassa liofilizada foi mais vermelha, mais escura e de cor menos saturada. Não houve diferença entre os conteúdos de oxicarotenóides. Embora resulte em uma menor recuperação, a atomização foi mais rápida, mais produtiva e apresentou rendimento equivalente à liofilização, o que a torna o método de escolha para a obtenção de biomassa de R. gelatinosus.

Palavras-chave: biomassa; pigmentos biológicos; Rubrivivax gelatinosus.

\section{Introduction}

Color is an important attribute in food acceptance. It can is a quality attribute since things are perceived based on sensory impressions (BARUFFALDI; OLIVEIRA, 1998). Carotenoids are the natural pigments responsible for yellow, orange, and red colors in foods, pharmaceuticals, cosmetics, and animal feed. They consist of two classes of molecules: carotenes, which are strictly hydrocarbons, and xanthophylls or oxycarotenoids, which contain oxygen (JOHNSON, 2007).

Besides being widely used as colorants, some carotenoids can also be used to enrich foods due to their antioxidant properties, to the fact that they act as vitamin A precursor are considered beneficial for health, among other things (NIIZU,
2003; VALDUGA et al., 2009). The use of colorants in animal feeds provides typical pigmentation improving their consumer acceptance (MOTTA; VIDAL; MATTOS, 2009). For instance, canthaxanthin and bixin may be added to poultry feed to enhance egg yolk color and to broiler chicken feed to enhance skin and meat color, thus aggregating commercial value to these products (GARCIA et al., 2009; CARNEIRO, 2010). $\beta$-caroten and astaxanthin are the main pigments used in aquaculture (AKSU; EREN, 2007). These synthetic pigments are generally used to provide color to salmonids and trouts to make them more attractive to consumers (TAKAHASHI; TSUKAMOTO; TABAT, 2008).

\section{Received 10/1/2012}

Accepted 29/9/2012 (005543)

${ }^{1}$ Laboratório de Alimentos, Programa de Pós-graduação em Ciência Animal, Departamento de Apoio, Produção e Saúde Animal, Faculdade de Medicina Veterinária,

Universidade Estadual Paulista - UNESP, Rua Clóvis Pestana 793, Bairro Dona Amélia, CEP 16050-680, Araçatuba, SP, Brasil, e-mail: edson_fes@hotmail.com

${ }_{2}^{2}$ Faculdade de Medicina Veterinária, Universidade Estadual Paulista - UNESP, Rua Clóvis Pestana, 793, Bairro Dona Amélia, CEP 16050-680, Araçatuba, SP, Brasil

${ }^{*}$ Corresponding author 
In 1996, the expression Single Cell Protein (SCP) was coined to describe the protein production in the biomass of different microbial sources that could be obtained from many substrates, such as industrial by-products. The use of SCP in human or animal nutrition has positive aspects due to its typical high concentration of nutrients. Nevertheless, some negative aspects may also be attributed to SCP since its consumption predisposes to the development of gout and renal stones, in addition to the possibility of contamination with pathogenic and toxic substances (UYSAL; AYDOGAN; ALGUR, 2002; NASSERI et al., 2011).

The great amounts of effluents from animal food industries has led to investigations on the use of these by-products as substrates for the growth of phototrophic bacteria that consume organic matter and produce bacterial biomass (PONSANO; LACAVA; PINTO, 2003; AZAD et al., 2004; KANTACHOTE; TORPEE; UMSAKUL, 2005). Due to the nutritional composition of this biomass, some authors have suggested its use as a biofertilizer and animal feed supplement (PONSANO; LACAVA; PINTO, 2003; PONSANO et al., 2004; KANTACHOTE; TORPEE; UMSAKUL, 2005). Studies conducted with a particular phototrophic bacterium, Rubrivivax gelatinosus, in effluents from poultry and fish industries demonstrated this micro-organism ability to produce biomass that can be used as a nutritional and color additive in animal feed (PONSANO; LACAVA; PINTO, 2003; PONSANO et al., 2004; PONSANO; LIMA; TORRES, 2011; SANTO, 2011).

Drying of food and feed ingredients may be performed in different dryers, according to the initial properties and final desired characteristics of the product and economic factors (BARUFFALDI; OLIVEIRA, 1998). Freeze drying, a technique based on water removal by sublimation, is used to obtain several industrial products (ROSA; TSUKADA; FREITAS, 2006). During freeze drying, substances are not exposed to high temperatures; therefore the freeze-dried products preserve their initial nutritious characteristics, and return to their original shape and texture instantaneously achieving long shelf life (BARUFFALDI; OLIVEIRA, 1998; PEREDA et al., 2005). This technique was used by Ponsano et al. (2002); Ponsano, Paulino and Pinto (2008); Lima, Ponsano and Pinto (2011) and Santo (2011) to dry R. gelatinosus biomass produced in industrial wastewater. On the other hand, spray drying technique consists of maximizing heat transfer, and it can be used for any product with a liquid-like behavior (BARUFFALDI; OLIVEIRA, 1998). Due to its versatility and speed, spray drying became the most used drying technique for heat sensible substances such as foods and biological materials (LABMAQ..., 2010; ROSA; TSUKADA; FREITAS, 2006). During this process, water removal is very fast, the final quality of the products is excellent, texture is maintained, and rehydration is quick (BARUFFALDI; OLIVEIRA, 1998; FELLOWS, 2006). Since the bacterial culture for biomass production in industrial effluents has a liquid-like behavior, it is feasible that spray drying technique works well for removing water from this product; hence we decided to investigate that possibility.

Therefore, the aim of this research was to investigate the effects of using freeze and spray drying to obtain of $R$. gelatinosus biomass on the process parameters (yield, product recovery, and productivity) and on the product characteristics (composition, oxycarotenoids, and color).

\section{Materials and methods}

\subsection{Microorganism, cell culture reactivation, pre-inoculum, and inoculum}

Rubrivivax gelatinosus isolated from poultry slaughterhouse wastewater and characterized by morphological and biochemical tests was used in this experiment (PONSANO; LACAVA; PINTO, 2002). The cells were maintained in Pfennig semi-solid agar, and cell culture reactivation was performed according to the procedures previously described by Ponsano et al. (2002).

For the initial inoculum preparation, cells were grown in Pfennig liquid medium under anaerobiosis (fully filled screwcrap tubes), $32 \pm 2{ }^{\circ} \mathrm{C}$ and 1,400 \pm 200 lux for approximately 3 days until a slight red color developed. For the final inoculum, an aliquot from initial inoculum was transferred at $1 \%(\mathrm{v} / \mathrm{v})$ to the same medium, and incubation was carried out in glass cylinders under the same conditions described before until optical density at $600 \mathrm{~nm}$ reached 0.5 (PONSANO; LACAVA; PINTO, 2003).

\subsection{Substrate preparation}

Tilapia fish processing wastewater used in this experiment was donated by Tilapia do Brasil Inc. (Buritama City, SP, Brazil) and was made up of effluents from killing, scaling, gutting, cleaning, skinning, filleting and freezing, and cleaning operations; it underwent treatment (grating) and was collected. In the laboratory, this effluent was filtered in $50 \mu \mathrm{m}$ mesh fast filter (Gardena 1731; 3,000 $\mathrm{L} \mathrm{h}^{-1}$ ) for the removal of gross particles, and it was heat treated (Incomar LTLT tank) at $65^{\circ} \mathrm{C} / 30 \mathrm{~min}$. After that, the wastewater was cooled to room temperature to receive the bacterial inoculum.

\subsection{Production and drying of biomass}

The bacterial inoculum was added to the treated wastewater at $1 \%(\mathrm{v} / \mathrm{v})$, and anaerobic cultivation was carried out in $100 \mathrm{~L}$ glass reactors at $32 \pm 2{ }^{\circ} \mathrm{C}$ and 2,000 \pm 500 lux for seven days. After that time, the liquid bacterial cultures exhibited purplered color, peculiar to $R$. gelatinosus growth in that substrate. Six bacterial cultivations were performed. The culture was filtered at $0.2 \mu \mathrm{m}, 1.5 \mathrm{~m}^{3} \mathrm{~h}^{-1}$ and 4.5 bar (Frings), resulting in a concentrate containing the cell mass. This concentrate was divided into two portions that were submitted to the two drying techniques. For the freeze drying process, the concentrate was initially centrifuged at $3,400 \mathrm{~g}$ for 30 minutes at $5{ }^{\circ} \mathrm{C}$ (Incibras Spin VI), and the resulting slime was frozen at $-40^{\circ} \mathrm{C}$ and freeze dried under vacuum at $140 \mathrm{~L} \mathrm{~min}^{-1}$ for 48 hours (Liobras L 101). Hand grinding was performed to obtain the powder freeze dried biomass. For the spray drying process, the concentrate was fed directly into a spray dryer (Labmaq MSDi 1,0) at entrance temperature of $120^{\circ} \mathrm{C}$, exit temperature of $65^{\circ} \mathrm{C}$, compressed air at $35 \mathrm{~L} \mathrm{~min}^{-1}$, and peristaltic pump at $1 \mathrm{~L} \mathrm{~h}^{-1}$ to produce the powder spray dried biomass. Six production processes (freeze and spray drying processes) were performed to obtain the powder biomass. 


\subsection{Yield, recovery, and productivity}

The yields of the drying processes were determined from the ratio between the solid matter of the final products and solid matter of the concentrate in the concentrate. Total solids in the biomasses were determined in an oven at $105^{\circ} \mathrm{C}$ until constant weight. For the concentrate, the total solids were determined by taking $100 \mathrm{~mL}$, which were initially evaporated in a water bath at $100{ }^{\circ} \mathrm{C}$, and then dried to constant weight in an oven at $105^{\circ} \mathrm{C}$. Biomass recovery was determined based on the weight of the final products obtained by the two techniques. Productivity was the ratio between the final amount of product formed and drying process time.

\subsection{Chemical composition}

To determine the proximate composition of the biomasses, the following determinations were performed in duplicate: moisture at $105^{\circ} \mathrm{C}$, lipids (extraction in ethyl ether), Kjeldahl $\mathrm{N}$ for proteins, and ash at $550^{\circ} \mathrm{C}$ (INSTITUTO..., 2008).

\subsection{Color}

Objective color was determined in the LCh space, in which the color attributes are L (Lightness), quality that differentiates a dark color from a light one; $C$ (Chroma), that denotes the color saturation; and $h(h u e)$, which defines the color itself by an angular measurement: $0^{\circ}$ (red), 90 (yellow), $180^{\circ}$ (green) and $270^{\circ}$ (blue) (HUNTERLAB, 2010). Measurements (illuminant D65 and $2^{\circ}$ observer) were obtained from the average of three consecutive pulses launched on the biomasses from the optical chamber of the MiniScan XE Plus (Hunter Lab) colorimeter. Previous calibration was performed with black and white tiles.

\subsection{Oxycarotenoids content}

For the determination of oxycarotenoids, an adaptation of Valduga (2005) methodology was used (duplicates for each sample). The pigments were extracted from the biomass with dimetilsulfoxide at $55{ }^{\circ} \mathrm{C} / 30 \mathrm{~min}$ and alternated cycles of ultrasound at $40 \mathrm{kHz}$ (Unique/USC 1800A) under shaking (Phoenix/P-56). Next, a mixture containing acetone:methanol $(7: 3, \mathrm{v} / \mathrm{v})$ was added, the tubes were centrifuged at 3,400 $\mathrm{g}$ and $5{ }^{\circ} \mathrm{C} / 10 \mathrm{~min}$, and the supernatant was transferred to a $50 \mathrm{~mL}$ volumetric flask. Successive extractions were performed until no color remained in the cells or solvent. Final dilutions were made up with methanol, and the quantification of oxycarotenoids was accomplished at $448 \mathrm{~nm}$ (Hitachi U-1000/U-1100). Total carotenoids were estimated according to Davies (1976) using the absorption coefficient of carotenoids suggested by LiaaenJensen and Jensen (1971).

\subsection{Statistical analysis}

The means were compared using the t-test and the GraphPad InStat Version 3.06 (VIEIRA, 1999); the significance level adopted was 5\%.

\section{Results and discussion}

The data shown in Table 1 are the average yield, product recovery, and productivity. Although the yields produced using both drying techniques were considered statistically equal $(p=0.3634)$, the amount of biomass recovered after spray drying was lower $(\mathrm{p}=0.004)$, and productivity was higher $(\mathrm{p}<0.0001)$ for this technique.

Although adhesiveness was not measured in this study, it may have been responsible for the lower product recovery for spray drying. Some foods and pharmaceuticals tend to adhere to the spray dryer chamber causing considerable losses during the drying process (BHANDARI; HOWES, 1999). On the other hand, this was not a problem for freeze drying. With regard to productivity, freeze drying required 48 hours for the water removal, but spray drying, under the experimental conditions used in this study, was accomplished within 2 hours; which explains the higher values of productivity found for this technique.

The low product recovery found for both drying techniques in this study can be justified by the growth conditions used since under anaerobic light conditions, are more likely to produce pigments than cells (PRASERTSAN; CHOORIT; SUWANNO, 1993).

Moisture contents were $98.71 \%$ for the concentrate obtained by membrane filtration, $3.65 \%$ for the spray dried biomass, and $4.15 \%$ for the freeze dried biomass. The mean proximate compositions for both products are shown in Table 2 (wet basis). The high concentration of proteins found in those products is a characteristic of phototrophic bacteria biomass, which indicates a probable use in animal feed (PONSANO; PINTO; GARCIANETO, 2003). Moisture content was higher for the freeze dried biomass ( $p=0.0022)$, while ash was higher for the spray dried biomass $(\mathrm{p}<0.0001)$. Proteins and lipids did not differ significantly between the products $(\mathrm{p}=0.355$ and $\mathrm{p}=0.3022$, respectively). The lower moisture content found for the spray dried biomass shows that this technique was more effective at removing water, which may be explained by the intense contact

Table 1. Drying parameters of Rubrivivax gelatinosus biomasses obtained using spray and freeze drying ${ }^{1}$ techniques.

\begin{tabular}{lcl}
\hline \multicolumn{1}{c}{ Parameter } & Spray drying & Freeze drying \\
\hline Yield (\%) & $74.53 \pm 1.81^{\mathrm{a}}$ & $74.92 \pm 1.77^{\mathrm{a}}$ \\
Recovery $(\mathrm{g})$ & $12.32 \pm 0.98^{\mathrm{a}}$ & $16.86 \pm 0.48^{\mathrm{b}}$ \\
Productivity $\left(\mathrm{mg} \mathrm{h}^{-1}\right)$ & $6.17 \pm 0.72^{\mathrm{a}}$ & $0.351 \pm 0.011^{\mathrm{b}}$ \\
\hline
\end{tabular}

${ }^{1}$ Mean values and standard deviations. ${ }^{\mathrm{a}, \mathrm{b}}$ Means in the same row with different superscripts differ significantly $(\mathrm{p}<0.05)$ by the $\mathrm{t}$-test.

Table 2. Proximate composition (wet basis) of Rubrivivax gelatinosus biomasses obtained using spray and freeze drying ${ }^{1}$ techniques.

\begin{tabular}{lcc}
\hline \multicolumn{1}{c}{ Component (\%) } & Spray drying & Freeze drying \\
\hline Moisture & $3.65 \pm 0.2^{\mathrm{a}}$ & $4.15 \pm 0.19^{\mathrm{b}}$ \\
Ash & $6.65 \pm 0.32^{\mathrm{a}}$ & $4.33 \pm 0.41^{\mathrm{b}}$ \\
Crude protein & $54.24 \pm 2.19^{\mathrm{a}}$ & $55.41 \pm 1.92^{\mathrm{a}}$ \\
Lipid & $12.48 \pm 1.03^{\mathrm{a}}$ & $11.72 \pm 1.37^{\mathrm{a}}$ \\
Non-nitrogen fraction & $22.98 \pm 1.43^{\mathrm{a}}$ & $24.39 \pm 1.55^{\mathrm{a}}$ \\
\hline
\end{tabular}

${ }^{1}$ Mean values and standard deviations. ${ }^{\mathrm{a}, \mathrm{b}} \mathrm{Means}$ in the same row with different superscripts differ significantly $(\mathrm{p}<0.05)$ by the t-test. 
between the particles and the hot air (ROSA; TSUKADA; FREITAS, 2006). This was considered an important finding of this study, taking into account the association between water content and the stability of the biomass.

Some other authors investigated the proximate composition of R. gelatinosus, and they all agreed that it varies according to the substrate used for production as well as to its organic matter content. Ponsano, Lima and Torres (2011) used tilapia fish industry effluent as the substrate for the cultivation of the bacterium and found $57.39 \%$ protein, $11.08 \%$ lipids, $4.55 \%$ moisture, and $4.05 \%$ ash for the freeze dried biomass. These results are similar to those of this study. Ponsano, Lacava and Pinto (2003) used poultry slaughterhouse effluent as the substrate for the cultivation of the same bacterium and produced a freeze dried biomass containing $62.8 \%$ protein, $0.5 \%$ lipids, $7.1 \%$ moisture, and $4 \%$ ash.

All color attributes presented in Table 3 were higher for the spray dried product $(\mathrm{p}<0.0001)$, demonstrating that this biomass is clearer, less red, and it has a more saturated color as compared to the freeze dried product. Such a difference must probably be due to the higher dynamics of the spray drying process, in which temperature, pressure, and particle size may change the color of the final product (FELLOWS, 2006; LABMAQ..., 2010). Moreover, another factor that may explain the differences in the color attributes is the different water content of the biomasses since drying processes modify the surface of a product altering its reflectiveness and color (FELLOWS, 2006).

The average contents of oxycarotenoids in the biomass were 3.74 and $3.72 \mathrm{mg} \mathrm{g}^{-1}$ (dry basis) for the spray and freeze drying processes, respectively; these values were statistically the same $(\mathrm{p}=0.9293)$. These values are also similar to those found by Prasertsan, Jaturapornpipat and Siripatana (1997) for Rhodocyclus gelatinosus R7 grown in tuna fish industry wastewater (from 2.13 to $3.90 \mathrm{mg} \mathrm{g}^{-1}$ ). With respect to color, the determination of the carotenoids profile by High Performance Liquid Chromatography (HPLC) could explain the difference in color between the two processes evaluated.

In order to obtain good results with spray drying methodology, it is necessary to understand the physicochemical aspects of the materials involved as well as their interaction with the physical variables of the process (ROSA; TSUKADA; FREITAS, 2006; LABMAQ ..., 2010). The results presented in this study are preliminary data and, as soon as new studies are conducted, we intend to provide more data to make this

Table 3. Color attributes ( $L$ - Lightness, $C$ - Chroma, $h$ - hue) of Rubrivivax gelatinosus biomasses obtained using spray and freeze drying ${ }^{1}$ techniques.

\begin{tabular}{ccc}
\hline Color attribute & Spray drying & Freeze drying \\
\hline$L$ & $38.07 \pm 2.14^{\mathrm{a}}$ & $19.68 \pm 4.67^{\mathrm{b}}$ \\
$C$ & $23.85 \pm 0.84^{\mathrm{a}}$ & $10.09 \pm 1.92^{\mathrm{b}}$ \\
$h$ & $26.63 \pm 1.84^{\mathrm{a}}$ & $20.01 \pm 0.94^{\mathrm{b}}$ \\
\hline
\end{tabular}

${ }^{1}$ Mean values and standard deviations. ${ }^{\mathrm{a}, \mathrm{b}}$ Means in the same row with different superscripts differ significantly $(\mathrm{p}<0.05)$ by the t-test. a more profitable technique to obtain $R$. gelatinosus biomass. For instance, the use of additives such as modified starch, maltodextrin, and gum Arabic may be tested to reduce losses caused by adhesion and to improve product recovery (WANG; LANGRISH, 2009; LABMAQ ..., 2010). Further studies will also be accomplished in order to investigate the economic feasibility of using this product in animal feeding.

\section{Conclusions}

The comparison between spray and freeze drying techniques to obtain powder R. gelatinosus biomass showed that the products have the same protein and lipid contents, but the lowest moisture was found using the spray dried technique, which means better preservation. Despite some differences found in the color of the products, they had the same oxycarotenoids contents. Although product recovery was lower for the spray drying technique, this technique was faster, more productive and provided the same yield as freeze drying, which makes it the method of choice for obtaining of $R$. gelatinosus biomass.

\section{Acknowledgements}

The authors are grateful for the financial support provided by Fundação de Amparo à Pesquisa do Estado de São Paulo - FAPESP (process No 2009/12964-9), to Tilapia do Brasil S/A Inc. for the effluent, and to Labmaq do Brasil Inc. for conducting the spray drying experiments.

\section{References}

AKSU, Z.; EREN, A. T. Production of carotenoids by the isolated yeast of Rhodotorula glutinis. Biochemical Engineering Journal, v. 35, n. 2, p. 107-113, 2007. http://dx.doi.org/10.1016/j.bej.2007.01.004

AZAD, S. A. et al. Rhodovulum sulfidophilum in the treatment and utilization of sardine processing wastewater. Letters in Applied Microbiology, v. 38, n. 1, p. 13-18, 2004.

BARUFFALDI, R.; OLIVEIRA, M. N. Fundamentos da tecnologia de alimentos. São Paulo: Atheneu, 1998. v. 3, 317 p.

BHANDARI, B. R.; HOWES, T. Implication of glass transition for the drying and stability of dried food. Journal of Food Engineering, v. 40 , n. $1-2$, p. $71-79,1999$. http://dx.doi.org/10.1016/S02608774(99)00039-4

CARNEIRO, J. S. Corantes como aditivos em rações de poedeiras comerciais. 2010. 28 f. Tese (Doutorado em Ciência Animal)Escola de Medicina Veterinária, Universidade Federal de Goiás, Goiânia, 2010.

DAVIES, B. H. Carotenoid: chemistry and biochemistry of plant pigments. 2nd ed. London: Academic Press, 1976. v. 2, p. 38-165.

FELLOWS, P. J. Tecnologia do processamento de alimentos: princípios e prática. 2. ed. Porto Alegre: Artmed, 2006. 602 p.

GARCIA, E. A. et al. Desempenho e qualidade dos ovos de poedeiras comerciais alimentadas com semente de urucum (Bixa orellana L.) moída na dieta. Veterinária e Zootecnia, v. 16, n. 4, p. 689-697, 2009.

HUNTERLAB. Principios básicos de medida y percepción de color. version 1.2. HunterLab, 2001. Disponível em: <http://www. hunterlab.com/pdf/color-s.pdf>. Acesso em: 17 out. 2010.

INSTITUTO ADOLFO LUTZ - IAL. Métodos físico-químicos para análise de alimentos. São Paulo: IAL, 2008. 1020 p. Disponível em: 
<http://www.crq4.org.br/sms/files/file/analisedealimentosial_2008. pdf $>$. Acesso em: 14 maio 2011.

JOHNSON, J. D. Lutein and Zeaxanth: An Introduction to the Chemistry of Dietary Carotenoids. Tallahassee: Florida State University, 2007. Disponível em: <http://www.chm.bris.ac.uk/ motm/carotenoids/carotenoids.htm>. Acesso em: 01 ago. 2012.

KANTACHOTE, D.; TORPEE, S.; UMSAKUL, K. The potencial use of anoxygenic phototrophic bacteria for treating latex rubber sheet wastewater. Eletronic Journal of Biotechnology, v. 8, n. 3, 2005. http://dx.doi.org/10.2225/vol8-issue3-fulltext-8

LABMAQ DO BRASIL LTDA. Manual de operações do spray dryer MSD 5.0. Departamento de Engenharia, 2010. 65 p.

LIAAEN-JENSEN, S.; JENSEN, A. Quantitative determination of carotenoids in photosynthetic tissues: total carotenoid content. In: PIETO, A. S. Methods in enzimology: photosynthesis and nitrogen part A. New York: Elsevier, 1971. v. 23, cap. 56, p. 586-602.

LIMA, L. K. F.; PONSANO, E. H. G.; PINTO, M. F. Cultivation of Rubrivivax gelatinosus in fish industry effluent for depollution and biomass production. World Journal of Microbiology and Biotechnology, v. 27, n. 11, p. 2553-2558, 2011. http://dx.doi. org/10.1007/s11274-011-0725-3

MOTTA, J. H. S.; VIDAL, J. M. V.; MATTOS, D. C. Desenvolvimento de tecnologias para transporte de peixes visando exportação. In: CONGRESSO FLUMINENSE DE INICIAÇÃO CIENTÍFICA E TECNOLÓGICA, 2009, Campos dos Goitacazes. Resumos... Campos dos Goitacazes: UENF, 2009.

NASSERI, A. T. et al. Single cell protein: production and process. American Journal of Food Technology, v. 6, n. 2, p. 103-116, 2011. http://dx.doi.org/10.3923/ajft.2011.103.116

NIIZU, P. Y. Fontes de carotenóides importantes para a saúde humana. 2003. 87 f. Dissertação (Mestrado em Ciência de Alimentos)-Faculdade de Engenharia de Alimentos, Universidade Estadual de Campinas, Campinas, 2003.

PEREDA, J. A. O. et al. Tecnologia de alimentos: componentes dos alimentos e processos. Porto alegre: Artmed, 2005. v. 1, 294 p.

PONSANO, E. H. G.; LACAVA, P. M.; PINTO, M. F. Isolation of Rhodocyclus gelatinosus from poultry slaughterhouse wastewater. Brazilian Archives of Biology and Technology, v. 45, n. 4, p. 445-449. 2002.

PONSANO, E. H. G.; LACAVA, P. M.; PINTO, M. F. Chemical composition of Rhodocyclus gelatinosus biomass produced in poultry slaughterhouse wastewater. Brazilian Archives of Biology and Technology, v. 46, n. 2, p. 143-147, 2003. http://dx.doi. org/10.1590/S1516-89132003000200001

PONSANO, E. H. G.; LIMA, L. K. F.; TORRES, A. P. C. From a pollutant byproduct to a feed ingredient. In: MANTOVIC, D. (Ed.). Biomass - detection, production and usage. InTech, 2011. cap. 23, p. 461-472.
PONSANO, E. H. G.; PAULINO, C. Z.; PINTO, M. F. Phototrophic growth of Rubrivivax gelatinosus in poultry slaughterhouse wastewater. Bioresource Technology, v. 99, n. 9, p. 3836-3842, 2008. PMid:17905581. http://dx.doi.org/10.1016/j.biortech.2007.06.063

PONSANO, E. H. G.; PINTO, M. F.; GARCIA-NETO, M. Biomassa de Rhodocyclus gelatinosus para a promoção da pigmentação de gemas de ovos. Revista Higiene Alimentar, v. 17, n. 104-105, p. 155-156, 2003.

PONSANO, E. H. G. et al. Evaluation of Rhodocyclus gelatinosus biomass for broiler pigmentation. Journal of Applied Poultry Research, v. 11, n. 1, p. 77-82, 2002.

PONSANO, E. H. G. et al. Rhodocyclus gelatinosus biomass for egg yolk pigmentation. Journal of Applied Poultry Research, v. 13, n. 3, p. 421-425, 2004.

PRASERTSAN, P.; CHOORIT, W.; SUWANNO, S. Isolation, identification and growth condition of photosynthetic bacteria found in seafood processing wastewater. World Journal of Microbiology and Biotechnology, v. 9, n. 5, p. 590-593, 1993. http://dx.doi.org/10.1007/BF00386301

PRASERTSAN, P.; JATURAPORNPIPAT, M.; SIRIPATANA, C. Utilization and treatment of tune condensate by photosynthetic bacteria. Pure and Applied Chemistry, v. 69, n. 11, p. 2439-2445, 1997. http://dx.doi.org/10.1351/pac199769112439

ROSA, E. D.; TSUKADA, M.; FREITAS, L. A. P. Secagem por atomização na indústria alimentícia: fundamentos e aplicações. In: JORNADA CIENTÍFICA DA FAZU/FACULDADES ASSOCIADAS DE UBERABA, 5., 2006, Uberaba, Anais... Uberaba: FAZU, 2006.

SANTO, E. F. E. Comparação entre técnicas de secagem para a obtenção de biomassa de Rubrivivax gelatinosus. $2011.71 \mathrm{f}$. Dissertação (Mestrado em Ciência Animal)-Faculdade de Medicina Veterinária, Universidade Estadual Paulista, Araçatuba, 2011.

TAKAHASHI, N. S.; TSUKAMOTO, R. Y.; TABAT, Y. A. Truta salmonada. Panorama da Aquicultura, v. 18, n. 105, p. 28-33, 2008.

UYSAL, H.; AYDOGAN, M. N.; ALGUR, O. F. Effect of single cell protein as a protein source in drosophila culture. Brazilian Journal of Microbiology, v. 33, n. 4, p. 314-317, 2002.

VALDUGA, E. Bioprodução de compostos voláteis e carotenóides por Sporodiobolus salmonicolor CBS 2636. 2005. $189 \mathrm{f}$. Tese (Doutorado em Engenharia Química)-Universidade Federal de Santa Catarina, Florianópolis, 2005.

VALDUGA, E. et al. Produção de carotenóides: microrganismos como fonte de pigmentos naturais. Química Nova, v. 32, n. 9, p. 2429-2436, 2009.

VIEIRA, S. Estatística experimental. 2. ed. São Paulo: Atlas, 1999. 192 p.

WANG, S.; LANGRISH, T. A review of process simulations and the use of additives in spray drying. Food Research International, v. 42, n. 1, p. 13-25, 2009. http://dx.doi.org/10.1016/j.foodres.2008.09.006 